\title{
Varnishes with Biocidal Activity: A New Approach to Protecting Artworks
}

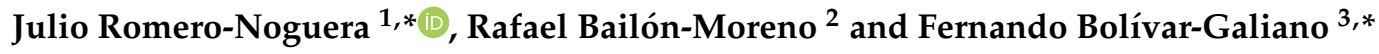 \\ 1 Department Painting, Faculty of Fine Arts, University of Seville, Laraña 3, 41003 Seville, Spain \\ 2 Department Chemical Engineering, Faculty of Sciences, University of Granada, Avenida de Fuente Nueva, \\ s/n, 18071 Granada, Spain; bailonm@ugr.es \\ 3 Deparment Painting, Faculty of Fine Arts, University of Granada, Avenida de Andalucía s/n, \\ 18014 Granada, Spain \\ * Correspondence: juliorn@us.es (J.R.-N.); fbolivar@ugr.es (F.B.-G.)
}

Received: 29 July 2020; Accepted: 12 October 2020; Published: 19 October 2020

\begin{abstract}
Keeping agents that cause biodeterioration under control is a common task in restoring and conserving artworks. However, there are very few studies, specifically those concentrating on pictorial works, that provide solutions compatible with the complex mix of organic and inorganic materials to be found in such cultural assets. This study aims to use biocide products that are commonly used in this field (benzalkonium chloride, o-phenylphenol, and tributyltin naphthenate) and which are associated with natural varnishes with a long tradition in artistic practices, in order to protect paintings and polychrome sculptures from environmental fungi and bacteria without altering the original materials or the visual appearance of the artworks. The effectiveness or innocuousness of the treatments was tested chemically and visually via optical microscopy, gas chromatography-mass spectrometry (GC-MS), and a multidimensional scaling analysis (MDS); the treatments produced good results as regards the inhibition of microbial growth and scarce interaction with the artistic materials being studied.
\end{abstract}

Keywords: biocides; terpenoid varnishes; painting; fungi; bacteria; biodeterioration; GC-MS; MDS

\section{Introduction}

Biological agents are one of the main causes of deterioration in cultural assets, and biocide products are among the solutions used to control them [1-4]. The use of these substances has been studied in significant papers focusing principally on treating ornamental stone, and these have been the main source of information on the matter until now [5-9]. Different products' action, toxicity, chemical stability, and interactions with the original materials have been evaluated in order to apply the treatments more effectively, meaning an approach that is innocuous, has a low-cost, and has low human and environmental toxicity for the artistic materials [10-15].

Studies focusing on paintings show the problems in applying biocide treatments to different types of polychromies, as well as the difficulty in eliminating microorganisms without altering the pictorial layer [16,17]. There are few products available for use on these cultural assets due to a lack of data about their necessary harmlessness towards the pigments and film-forming materials (binders and varnishes) that make up pictorial artworks, as well as the long-term effects on them [18]. The most commonly used biocides were not created specifically for use on cultural heritage; rather, they are disinfectants and pesticides for broad industrial usage. They fall within groups of chemicals such as the organometallic and nitrogen compounds, phenols, and quaternary ammonium derivatives [14,19-21].

There is also a rather limited range of methods for applying paint treatments [14]. The most common ones usually involve applying biocides in liquid form and fumigation with gases. One possible 
alternative that has been explored very little is to use materials with biocide incorporated. Restorers often carry out these tasks empirically, mixing them with water repellents or consolidants, but only in the area of mortars for restoration have serious attempts been made to obtain products with biocidal activity [22-24].

This study raises the possibility of using varnishes with incorporated biocide to give artworks protection against environmental microorganisms. Terpenic varnishes have traditionally been used as the final layer of protection so that they can act as a barrier between the pictorial layer and the external environment. It should be noted that they are susceptible to microbial colonization, although they are a restrictive substrate only suitable for microorganisms with certain metabolic and physiological capabilities (production of spores, resistance to a shortage of nutrients, resistance to xeric environments, etc.). Penicillium and Aspergillus are the most commonly described fungi associated with biodeterioration in polychrome artworks, and the genus Bacillus and Arthrobacter among bacteria [25-29]. Biodeterioration of these materials has been studied in past publications, which have described different analytical markers for these processes [30-33].

Nevertheless, terpenic varnishes naturally suffer from ageing processes that lead to phenomena such as yellowing and a loss of transparency. A common restoration task is to completely or partially eliminate them and revarnish the artworks. This can be done with products with incorporated biocide, which can add extra protection to the pictorial layer against microbial biodeterioration of paintings and polychrome sculptures.

The use of varnishes with biocidal activity has been studied very little until now. Souza and Gaylarde [34] evaluated the colonization of pinewood varnished with an unspecified alkyl resin with an incorporated biocide based on 2,3,5,6-tetrachloro-4 (methyl sulphonyl)-pyridine at a concentration of $0.3 \%$. They concluded that the effects on the varnish layer, measured using the changes on the surface observed microscopically, were significantly lower than in the same varnish not treated with biocide.

Our research group also contributed some results in this area [35], which we shall look at in greater detail in this work. We propose using biocides associated with natural diterpene resins such as colophony (rosin), sandarac, and Manila copal, which are widely used in fine arts as the final layer of protection against biodeterioration in artworks (mainly paintings and polychrome sculptures). Their effectiveness against selected bacteria and fungi is tested in this study using optical microscopy, gas chromatography-mass spectroscopy (GC-MS), and a multidimensional scaling analysis (MDS). On the whole, we found that the treatments gave good results in inhibiting microbes from developing and in chemical innocuousness for varnishes.

\section{Materials and Methods}

\subsection{Varnishes and Biocides}

The standard colophony obtained by distillation from pine resin was supplied by RCM (Madrid, Spain). The varnish was prepared in the proportion of $100 \mathrm{~g}$ of resin per $175 \mathrm{~mL}$ of purified turpentine essence, supplied by Titan (Barcelona, Spain). Sandarac of Tetraclinis articulata and Manila Copal of Agathis dammara were supplied by Caremi Pigmentos (Seville, Spain). These varnishes were prepared in the proportion of $100 \mathrm{~g}$ of resin per $200 \mathrm{~mL}$ of absolute ethanol (Merck, Barcelona, Spain).

The biocides selected for the study were benzalkonium chloride (alkyl dimethyl benzyl ammonium chloride; CTS, Madrid, Spain), sodium-2-phenylphenolate, a solid alkaline formulation of o-phenylphenol (Preventol ${ }^{\circledR}$ ON Extra, Kremer Pigmente, Aichstetten, Germany), and tributyltin naphthenate (tributyl-mono (naphthenoyloxy) stannane; Metatin N 5810/10, Acima Chemical Industries, Buchs, Switzerland). They all are widely used in restoration and are representative of significant chemical groups of substances used in this field $[14,19,21]$. 


\subsection{Microorganisms}

The microorganisms listed here were selected on the basis of their capacity for growing and causing chemical changes in resins, as reported in earlier works [30-33].

- Colophony: Chrysonilia sitophila and Bacillus amyloliquefaciens

- Sandarac: Chrysonilia sitophila, Penicillium chrysogenum, and Streptomyces celluloflavus

- Manila copal: Chrysonilia sitophila, Phoma herbarum, and Arthrobacter oxydans

The fungus Penicillium chrysogenum (Pc) (CECT-2306), and the bacteria Streptomyces celluloflavus (Sc) (CECT-3242), Bacillus amyloliquefaciens (Ba) (CECT-493), and Arthrobacter oxydans (Ao) (CECT-386) came from stock collections belonging to the Spanish Type Culture Collection (CECT, Colección Española de Cultivos Tipo, Universidad de Valencia, Spain). The fungi Chrysonilia sitophila (Cs) and Phoma herbarum $(\mathrm{Ph})$ were isolated from the surface of the oil on the canvas paintings of the Fine Arts Museum of Granada (Spain) entitled Allegory of Death (by P. Toma) and St. Francis of Assisi (anonymous), both from the 17th century and are severely affected by biodeterioration processes (Figure 1). Samples were taken from the painting using a noninvasive sampling procedure [36] of rubbing a dry sterile cotton bud, suitable for isolations in culture media (Class IIa) (Eurotubo, Deltalab, Barcelona, Spain), on the surface of the painting over an area of $2 \mathrm{~cm}^{2}$. Cultivation assays were performed immediately on these samples. The cotton swabs were inoculated directly onto Sabouraud-chloramphenicol Agar plates (Scharlab, Barcelona, Spain), which were incubated at $28^{\circ} \mathrm{C}$ for two weeks. During this period, colonies exhibiting a different morphology and appearance were btransferred to PDA culture plates (Scharlab, Barcelona, Spain) to obtain pure strains. All purified strains were stored in $70 \%$ glycerol at $-80{ }^{\circ} \mathrm{C}$ for conservation.
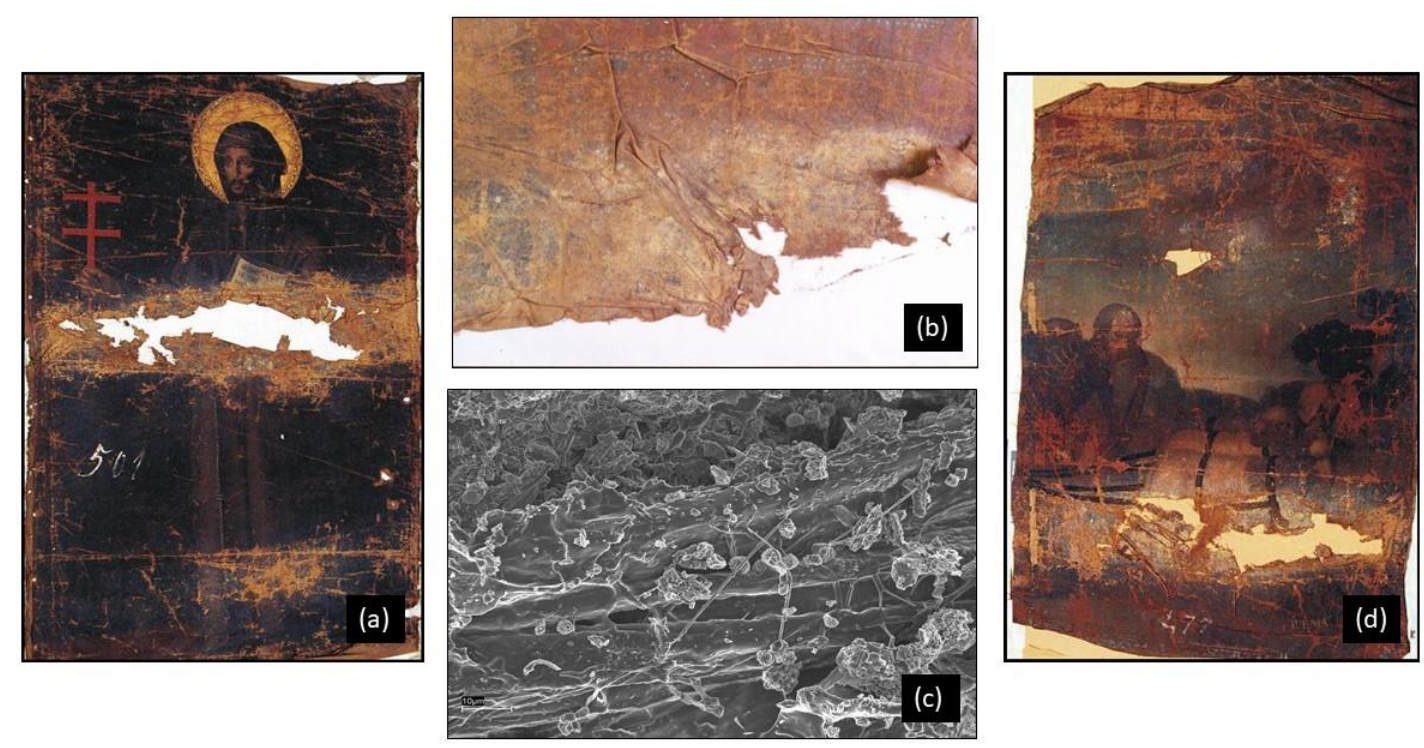

Figure 1. Overview of two paintings colonized by fungi, the St. Francis of Assisi (anonymous) (a) and the Allegory of Death (by P. Toma) (b), a detail of the biodeterioration pattern observed on the St. Francis of Assisi painting (c), and a SEM image of C. sitophila (d).

In order to obtain fungal spores, lyophilized collection stocks were hydrated in CM broth (Oxoid, Hampshire, UK) and incubated for one week $\left(28^{\circ} \mathrm{C}, 75 \% \mathrm{RH}\right)$. Afterwards, cultures were spread on a solid malt agar medium (Oxoid, Hampshire, UK) and incubated for 15 days. Sporulated cultures were resuspended in $2 \mathrm{~mL}$ of Tween 80 at $0.1 \%$ (Aldrich, Madrid, Spain). After centrifugation, pellets were washed and resuspended in $2 \mathrm{~mL}$ of distilled water. The suspensions were then filtered through glass 
wool to eliminate any remains of mycelium. After a count in a Neubauer chamber, the concentration was adjusted to $10^{6}$ spore $\mathrm{mL}^{-1}$.

As for bacteria, the lyophilized strains collected were rehydrated in a TSB medium (Oxoid, Hampshire, UK), and seeded after $48 \mathrm{~h}$ of incubation in TSA medium (Oxoid, Hampshire, UK). Using these cultures, inocula were prepared in a TSB medium and kept incubated for $24 \mathrm{~h}$. Afterwards, they were centrifuged and washed with distilled water to eliminate any remains of the culture medium, and resuspended in distilled water. Using the growth curve, the inocula were adjusted to $10^{7}-10^{8}$ cells $\mathrm{mL}^{-1}$.

\subsection{Sample Preparation}

In order to prepare varnish samples with biocide incorporated, solutions in ethanol (Sigma-Aldrich, Spain) at $10 \%(w / v)$ of o-phenylphenol and at $10 \%(v / v)$ of tributyltin naphthenate and benzalkonium chloride were mixed with the varnishes at a concentration of $3 \%(v / v)$. To help prepare the mixtures, a small amount $(0.1 \% v / v)$ of the nonionic surfactant Tween 80 (Sigma-Aldrich, Spain) was also added in the case of colophony. These varnishes with biocide were brush-applied to the surface of standard-sized glass slides $(24 \times 80 \mathrm{~mm})$ and were allowed to dry in the dark for 90 days. It was not possible to obtain a homogeneous, perfectly transparent mixture of o-phenylphenol with the sandarac and Manila copal varnishes, so those samples were not used for this study.

Solutions of the biocides were also prepared at $3 \% v / v$ (tributyltin naphthenate and benzalkonium chloride) and at $3 \% w / v$ (o-phenylphenol) in distilled water, which were applied by brush onto the surface of samples, namely standard-sized glass slides $(24 \times 80 \mathrm{~mm})$ varnished with the resins under study, which were allowed to dry in the dark for 90 days before applying the biocides on them.

In summary, two variants of samples were prepared: samples with biocide (3\%) dried in darkness for 90 days, and samples of varnish dried in darkness for 90 days before having a biocide applied to them (3\%). Similarly, control samples of the varnishes without biocide were also prepared to follow the progress of microorganisms and possible chemical changes with no biocidal treatment.

The Manila copal and sandarac samples treated with o-phenylphenol and the sandarac ones treated with tributyltin naphthenate (spread on) were discarded for this study because an increase in the opacity of the varnish was observed when they interacted with these products, which is incompatible with their use in artworks (Table 1).

Table 1. Samples included in the study.

\begin{tabular}{cccc}
\hline Varnish & Colophony & Sandarac & Manila Copal \\
\hline Microorganisms & Cs, Ba & Cs, Pc, Sc & Cs, Ph, Ao \\
\hline Biocides & $\begin{array}{c}\text { Benzalkonium chloride } \\
\text { (mixed, spread) } \\
\text { Metatin N } \\
\text { (mixed, spread) }\end{array}$ & $\begin{array}{c}\text { Benzalkonium chloride } \\
\text { (mixed, spread) } \\
\text { Preventol ON } \\
\text { (mixed, spread) }\end{array}$ & $\begin{array}{c}\text { Benzalkonium chloride } \\
\text { (mixed, spread) } \\
\text { (mixed) }\end{array}$ \\
$\begin{array}{c}\text { Metatin N } \\
\text { (mixed, spread) }\end{array}$ \\
\hline
\end{tabular}

$\mathrm{Cs}=\mathrm{C}$. sitophila; $\mathrm{Pc}=\mathrm{P}$. chrysogenum $; \mathrm{Ph}=$ Phoma herbarum; $\mathrm{Ao}=$ Arthrobacter oxydans; $\mathrm{Ba}=\mathrm{B}$. amyloliquefaciens.

In summary, five groups of test specimens were prepared so as to compare the possible chemical changes produced by the microorganisms in the varnishes studied in samples treated and not treated with biocides: type 1, varnish only (blank samples); type 2, varnish treated with biocides but not inoculated with microorganisms; type 3, varnish not treated with biocides but inoculated with microorganisms; type 4, varnish treated with biocides (mixed) and inoculated with microorganisms; type 5, varnish treated with biocides (spread) and inoculated with microorganisms.

\subsection{Monitoring Growth}

Each type of fungus and bacteria were inoculated separately in samples with several drops $(75 \mu \mathrm{L})$ of spore or bacterial suspensions respectively $\left(10^{7}-10^{8}\right.$ cells $\left.\mathrm{mL}^{-1}\right)$, as described in Section 2.2. 
Previous experiments helped us to establish the optimal conditions for incubating the model varnish specimens. The specimens were incubated for 30 days in darkness at $28{ }^{\circ} \mathrm{C}$ and $90 \% \mathrm{RH}$, water activity $(\mathrm{aw})=0.85$.

The fungal cultures were monitored by microscope to study the production of mycelium from the initial suspension of spores in distilled water both in the presence and absence of biocides. All of the samples were observed after a time of $0 \mathrm{~h}, 24 \mathrm{~h}, 48 \mathrm{~h}$, and five, ten, fifteen, and thirty days using a Nikon Eclipse TS100 microscope equipped with a Nikon DS-5M digital camera.

\subsection{Gas Chromatography-Mass Spectrometry (GC-MS)}

The GC-MS technique was used to evaluate the chemical changes caused by the proposed treatments and the microorganisms under study. A sterile scalpel was used to scrape the samples from the glass slides, providing about $5 \mathrm{mg}$ per sample. These were dissolved in $25 \mu \mathrm{L}$ of benzene in test tubes, into which $500 \mu \mathrm{L}$ of chloroform was added for $5 \mathrm{~min}$ to extract the organic components. Once filtered, the supernatants were subjected to a vacuum to evaporate the solvent in $2 \mathrm{~mL}$ vials, then the dry residue obtained was processed by adding $30 \mu \mathrm{L}$ of benzene and $30 \mu \mathrm{L}$ of (m-trifluoro-methylphenyl) trimethylammonium hydroxide (Meth-Prep II, Alltech, Stamford, UK) to each vial. The reaction mixture was shaken for $4 \mathrm{~min}$ at room temperature, and $2 \mu \mathrm{L}$ of the sample solution was injected into an Agilent 7890A gas chromatograph (Agilent Technologies, Santa Clara, CA, USA) with a Combi-xt PAL sample injector, coupled to a Waters mass spectrometer, Quattro micro GC (Waters, Milford, MA, USA).

Chromatographic separations were achieved in a capillary column (WCOT; wall coating open tubular) ZB-5MS, $30 \mathrm{~m} \times 0.25 \mathrm{~mm}$ I.D. with $0.25 \mu \mathrm{m}$ film thickness. The chromatographic conditions for the GC-MS analysis were as follows: injector temperature $=250^{\circ} \mathrm{C}$, transfer line temperature $=250{ }^{\circ} \mathrm{C}$, oven temperature $=140{ }^{\circ} \mathrm{C}(2 \mathrm{~min}$. $), 4{ }^{\circ} \mathrm{C} / \mathrm{min}$ to $300{ }^{\circ} \mathrm{C}$ then isothermal for $5 \mathrm{~min}$. The carrier gas was helium at a flow-rate of $1 \mathrm{~mL} / \mathrm{s}$. The samples were injected in splitless mode. Mass spectra were performed in total ion monitoring mode (mass range 50-550 m/z), and ions were generated by electron impact ionization $(70 \mathrm{ev})$. The source temperature was $210^{\circ} \mathrm{C}$. A Masslynx v.4.0 data system was used for data acquisition and processing, and the peak area (TIC) data were used to obtain the peak area percentage value.

Calculations were based on values of the normalized peak area $\mathrm{Ni}$, defined as the percentage of peak area of each individual compound relative to the set of peak areas of the $n$ components found in the model varnish:

$$
N i=\frac{A i}{\sum_{i=1}^{n} A i} 100
$$

where $A i$ is the peak area of each of the n compounds found in the chromatogram. Control samples inoculated with distilled water and incubated under the same conditions as those of the samples inoculated with microorganisms were also analyzed to evaluate the composition of the varnishes studied in the absence of microorganisms. The changes in composition were determined by establishing a $\Delta \mathrm{Ni}$ parameter, defined as the increase or decrease in $\mathrm{Ni}$ for each analyte in relation to the values corresponding to the control sample Nio.

$$
\Delta \mathrm{Ni}=\mathrm{Ni}-\mathrm{Nio}
$$

Three replicates were used for each sample. The repeatability found under the experimental conditions and the relative standard deviations, calculated using the formula RSD = (standard deviation/mean of the normalized peak area) $\times 100 \%$, fell within the range $1-5 \%$ for all the compounds analyzed. A Student's $t$-test was used for a comparison of the differences between mean values of inoculated and noninoculated blank samples. Only the values with a $p<0.05$ were considered statistically significant. 


\subsection{MDS Analysis}

In order to evaluate the analytical data obtained by GC-MS, an MDS (multidimensional scaling) statistical analysis was carried out. Each sample included in the study can be represented by a point in a multidimensional space in which the $n$ dimensions in the space are the $N i$ values of each of the $n$ components of the varnish. The analogous chemical composition samples will be found near this multidimensional space, whereas those with a different chemical composition will be further away. Since it is not possible to visualize spaces of more than three dimensions, it is common to resort to techniques to decrease the scale and project the $n$ dimensions of a multidimensional space onto a bidimensional space by means of an MDS analysis, which enables the chemical changes produced by the microorganisms and treatments tested to be represented in a simplified diagram. In this study, the MDS analysis was carried out using the ASCAL command from the IBM SPSS Statistics ${ }^{\circledR} 26.0$ software for 64 bits. For each varnish, a matrix was constructed of Euclidean distances between the different samples. For each pair of samples $i$ and $j$, the Euclidean distance $d_{i j}$ was calculated according to the equation:

$$
d_{i j}=\sqrt{\left(x_{i}-x_{j}\right)^{2}+\left(y_{i}-y_{j}\right)^{2}+\left(z_{i}-z_{j}\right)^{2}+\cdots}
$$

where the values $x, y, z$, etc., are the $N i$ values of each component of the varnish in samples $i$ and $j$. To improve the quality of the MDS graphs obtained with IBM SPSS Statistics, the resulting data from the analysis were processed with a Microsoft Excel 2013 spreadsheet.

\section{Results and Discussion}

\subsection{Monitoring Growth}

In the control samples not treated with biocides (type 3), the samples inoculated with C. sitophila in the three varnishes studied, the sandarac samples inoculated with P. chrysogenum and the Manila copal samples inoculated with $P$. herbarum, fungal growth was observed with mycelium developing from the spore suspensions after the incubation period. The growth observed appeared mainly in the first five days of incubation in all cases, which agrees with previous studies [30,33]. In the varnishes treated with surface biocides, only very little growth was observed in the colophony samples inoculated with C. sitophila (Figure 2), and in the samples prepared with biocide incorporated, there was no growth observed in any case.
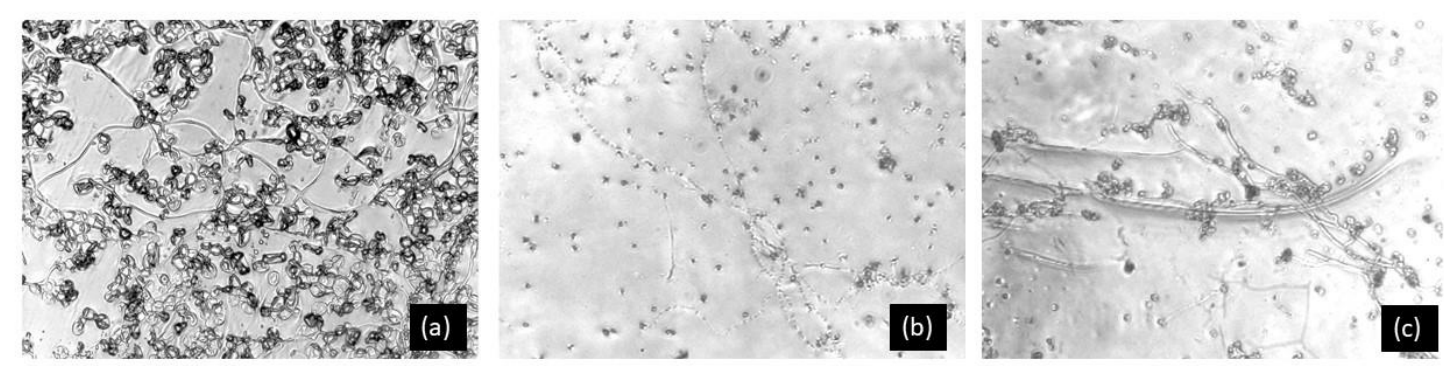

Figure 2. C. sitophila in colophony not treated with biocides (a) $(400 \times)$ and treated with (b) Metatin N (spread, 100×) and (c) Preventol ${ }^{\circledR}$ ON (spread, 400x) after five days of incubation.

\subsection{Colophony}

The results from the GC-MS analysis are shown in Table 2. They include data from the blank samples (type 1); the samples not treated with biocides but inoculated with microorganisms (type 3 ) and the samples treated with biocides (types 4 and 5): fungal samples with growth and the samples inoculated with bacteria. The biocide treatments did not lead to any significant change in the original composition of the varnish. The GC-MS results for the type 2 samples were very similar to those 
obtained in the blank sample (type 1), so they have not been included in the table. The data from fungal samples in which no growth was recorded were also left out to simplify the study, since the data are very similar to the data from blank samples.

Table 2. GC-MS analysis ( $p<0.05$ in all cases) of the diterpenes from the colophony varnish and the samples inoculated with microorganisms (values expressed in $\mathrm{Ni}$ ).

\begin{tabular}{cccccccc}
\hline Test & $\begin{array}{c}\text { Sample } \\
\text { Type }\end{array}$ & DHA & AA & $\begin{array}{c}\text { 7-OH- } \\
\text { DHA }\end{array}$ & $\begin{array}{c}\text { 15-OH- } \\
\text { DHA }\end{array}$ & $\begin{array}{c}\text { 7-oxo- } \\
\text { DHA }\end{array}$ & $\begin{array}{c}\text { 15-OH-7- } \\
\text { oxo-DHA }\end{array}$ \\
\hline Colophony & 1 & $\mathbf{5 6 . 5}$ & $\mathbf{1 0 . 3}$ & $\mathbf{3 . 0}$ & $\mathbf{9 . 8}$ & $\mathbf{5 . 8}$ & $\mathbf{1 . 4}$ \\
Colophony-Cs & 3 & 51.3 & 0.0 & 2.8 & 8.9 & 17.2 & 3.3 \\
Colophony-Ba & 3 & 24.4 & 0.0 & 6.1 & 12.2 & 36.5 & 14.8 \\
Colophony Benzalkonium chloride (sp) Cs & 5 & 57.2 & 0.9 & 3.1 & 6.1 & 9.6 & 0.0 \\
Colophony Tributyltin naphthenate (sp) Cs & 5 & 58.9 & 0.8 & 3.3 & 5.6 & 8.9 & 0.0 \\
Colophony Orthophenyl phenol (sp) Cs & 5 & 56.4 & 11.4 & 1.8 & 5.3 & 3.0 & 0.0 \\
Colophony Benzalkonyum chloride (sp) Ba & 5 & 56.0 & 1.6 & 2.4 & 8.5 & 10.1 & 0.0 \\
Colophony Tributyltin naphthenate (sp) Ba & 5 & 55.7 & 1.0 & 3.1 & 7.3 & 11.7 & 0.0 \\
Colophony Orthophenyl phenol (sp) Ba & 5 & 54.5 & 2.0 & 2.0 & 7.8 & 7.8 & 0.0 \\
Colophony Benzalkonium chloride Ba & 4 & 57.1 & 2.4 & 1.6 & 6.8 & 6.1 & 0.0 \\
Colophony Tributyltin naphthenate Ba & 4 & 43.7 & 36.8 & 1.0 & 4.5 & 0.6 & 0.0 \\
Colophony Orthophenyl phenol Ba & 4 & 53.2 & 11.5 & 1.1 & 3.3 & 0.6 & 0.0 \\
\hline
\end{tabular}

DHA = dehydroabietic acid; AA = abietic acid; 7-oxo-DHA = 7-oxo-dehydroabietic acid; 15-OH-7-oxo-DHA = 15 hydroxy-7-oxo-dehydroabietic acid. Sample type: 1: varnish only (blank samples); type 3: varnish inoculated with microorganisms; types 4 and 5: varnish treated with biocides, mixed (4) and spread (sp), (5) and inoculated with microorganisms. $\mathrm{Cs}=\mathrm{C}$. sitophila $; \mathrm{Ba}=B$. amyloliquefaciens.

In the type 3 sample corresponding to B. amyloliquefaciens, a clear decrease was recorded in the case of the relative amount of abietic and dehydroabetic acids compared to the original composition of varnish, and a sharp rise in oxidized diterpenes with respect to the type 1 sample, especially 7-oxo-dehydroabietic and 7 oxo-15-hydroxy-dehydroabietic reported in C. sitophila and B. amyloliquefaciens (example: Colophony-Cs, $\triangle N i$ 7-oxo-DHA $=+11.4$; Colophony-Ba, $\triangle N i 7$-oxo-DHA $=+30.7 ; \Delta \mathrm{Ni}$ 15-OH-7-oxo-DHA $=13.4)$. These oxidative changes coincide with the chemical degradation patterns described for this varnish in previously published studies, and they may be related to the biological activity of the microorganisms tested [30,37-40].

These results differ significantly from those obtained with biocides (Figure 3). There was very little growth of the fungus $C$. sitophila observed in the type 5 samples (biocide spread), and none at all in those with the biocide incorporated (type 4), where growth was totally inhibited. In chemical terms, the oxidative processes described in the samples not treated with biocides did not occur, nor in the case of the fungus, nor with the bacteria, although with B. amyloliquefaciens there were changes in composition recorded in the samples treated with Metatin $\mathrm{N}$ (Colophony tributyltin naphthenate Ba, $\Delta N i \mathrm{AA}=-12.84 ; \Delta N i \mathrm{DHA}=+26.44)$, suggesting biological activity.

Figure 4 shows the MDS diagram for the colophony samples. It can be seen that the samples without biocide (type 3) inoculated with C. sitophila and B. amyloliquefaciens are far from the nucleus formed by the blank sample and the samples inoculated and also treated with the biocides. This nucleus contains chemical compositions very similar to the blank sample with no inoculation or treatment. In other words, the biocides not only totally or partially prevented microbial growth, but they also ensured that the chemical composition of the varnish did not change substantially. 

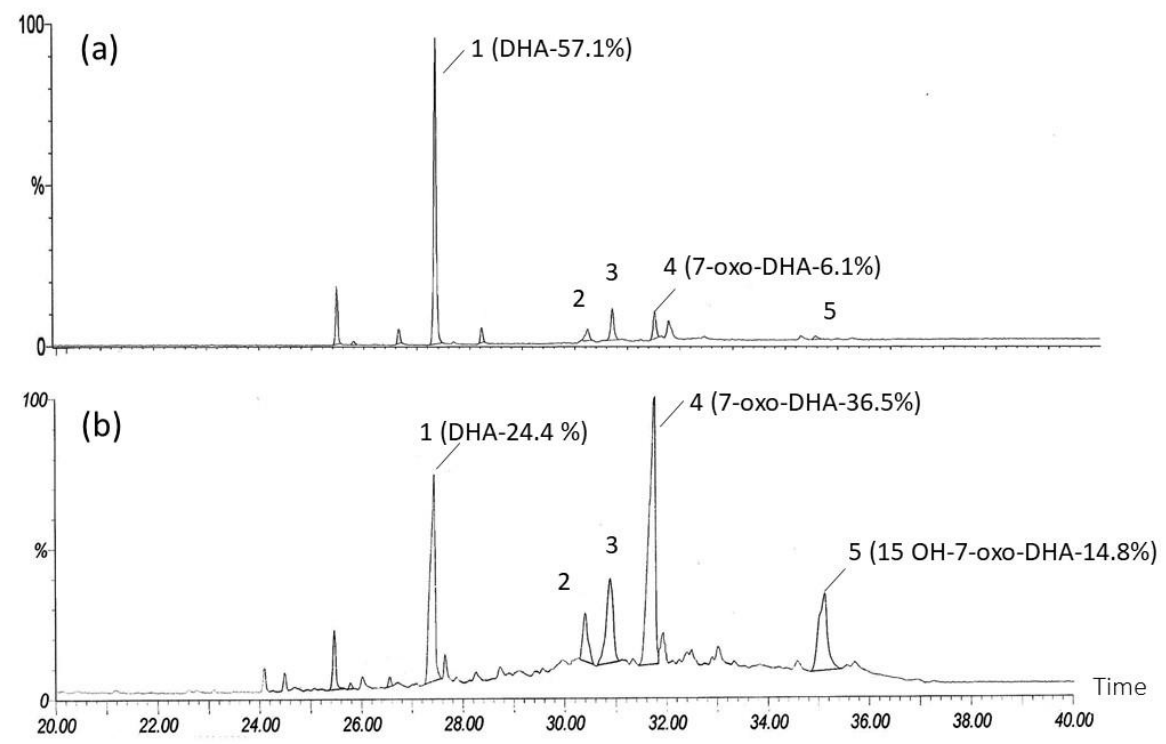

Figure 3. Chromatograms corresponding to (a) colophony varnish treated with Benzalkonium chloride and inoculated with B. amyloliquefaciens (type 4) and (b) colophony varnish not treated with biocides but inoculated with B. amyloliquefaciens (type 3). Values expressed in Ni. 1: DHA = dehydroabietic acid; 2: 7-OH-dehydroabietic acid; 3: 15-OH-dehydroabietic acid; 4: 7-oxo-dehydroabietic acid; 5: 15-OH-7-oxo-dehydroabietic acid.

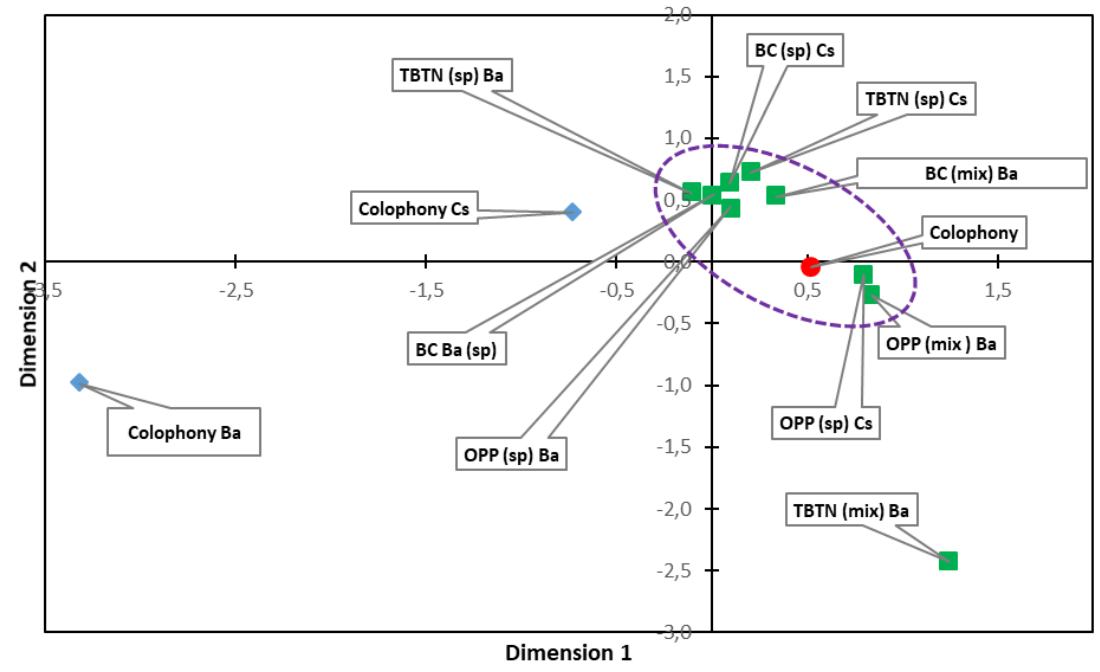

Figure 4. Multidimensional scaling (MDS) analysis of the colophony samples: blank sample (type 1, red circle); samples inoculated with microorganisms without biocide (type 3, blue diamonds); and samples inoculated with $\mathrm{Cs}$ and $\mathrm{Ba}$, and treated with the studied biocides (type 4 (mix), and 5 (sp), green squares). $\mathrm{BC}=$ benzalkonium chloride, TBTN $=$ tributyltin naphtenate, and OPP = ortophenyl phenol. $\mathrm{Cs}=$ C. sitophila; $\mathrm{Ba}=$ B. amyloliquefaciens.

The exception is the sample inoculated with B. amyloliquefaciens, the microorganism capable of producing the greatest chemical changes in the colophony, treated with the biocide tributyltin naphthenate mixed with the varnish. The biocide was not seen to be sufficiently effective, but nevertheless it managed to make the composition of the varnish somewhat closer to the blank sample than when it is inoculated with this bacteria type without the presence of the biocide. The results show the efficacy of the treatments tested, and they also resemble those obtained in a previous study carried out by our research group [35] that analyzed the changes produced by microorganisms inoculated in 
colophony resin samples treated on the surface with the biocides New Des (benzalkonium chloride), Biotin N, and Nipagine (methyl parahydroxybenzoate). The analyses by pyrolysis-GC-MS showed the efficacy of treatments with Biotin $\mathrm{N}$ on the growth of fungi and bacteria, without appreciable changes in the composition of the resins, and a lower effectiveness of the treatment with benzalkonium chloride and Nipagine.

\subsection{Sandarac}

The analytical results with the sandarac varnish are shown in Table 3. As in the case of colophony, the biocides studied did not lead to any significant change in the composition of the original varnish. The results from the GC-MS for the type 2 samples were very similar to those obtained in the blank sample, so they were not included in the table. However, the treatments tested inhibited the growth of the fungi $C$. sitophila and P. chrysogenum in all such samples studied. To simplify the study, the data for these latter samples are not included, since they are very similar to the data for the blank samples. The main chemical change observed in the sandarac inoculated with microorganisms but with no biocides (type 3) compared to the blank samples was a significant decrease in a hydroxylated derivative of sandaracopimaric acid to produce sandaracopimaric acid (example: Sandarac-Cs, $\Delta \mathrm{Ni} \mathrm{OH}$-sandaracopimaric acid $=+12.01$; Sandarac-Pc/Sc, $\Delta N i \mathrm{OH}$-sandaracopimaric acid $=-14,54$; Sandarac-Cs, $\Delta N i \mathrm{OH}$-sandaracopimaric acid $=-13,91)$. This has already been reported in previous studies $[33,41]$, although this did not generally occur in samples treated with biocides, which may be related to a drop in the microorganisms' biological activity caused by the proposed methods.

Table 3. GC-MS analysis ( $p<0.05$ in all cases) of the diterpenes in the sandarac varnish and the samples inoculated with microorganisms (values expressed in $\mathrm{Ni}$ ).

\begin{tabular}{|c|c|c|c|c|c|}
\hline \multirow{2}{*}{ Test } & \multirow{2}{*}{ Sample Type } & \multirow{2}{*}{ Manool } & \multicolumn{2}{|c|}{ Sandaracopimaric Isopimaric } & \multirow{2}{*}{ OH-Sandaracopimaric } \\
\hline & & & Acid & Acid & \\
\hline Sandarac & 1 & 25.79 & 47.34 & 8.02 & 14.54 \\
\hline Sandarac-Pc & 3 & 28.33 & 61.72 & 9.95 & 0 \\
\hline Sandarac-Cs & 3 & 27.47 & 64 & 7.9 & 0.63 \\
\hline Sandarac-Sc & 3 & 26.29 & 65.27 & 7.74 & 0 \\
\hline $\begin{array}{l}\text { Sandarac-Benzalkonium } \\
\text { chloride-Sc }\end{array}$ & 4 & 22.34 & 55.96 & 8.76 & 12.92 \\
\hline $\begin{array}{l}\text { Sandarac-Benzalkonium } \\
\text { chloride (sp)-Sc }\end{array}$ & 5 & 24.54 & 49.94 & 10.41 & 15.1 \\
\hline $\begin{array}{l}\text { Sandarac-Tributyltin } \\
\text { naphthenate-Sc }\end{array}$ & 4 & 18.43 & 54.33 & 13.58 & 13.65 \\
\hline
\end{tabular}

Sample type: 1: varnish only (blank samples); type 3: varnish inoculated with microorganisms; types 4 and 5: varnish treated with biocides mixed (4) or spread (5) and inoculated with microorganisms. Cs $=$ C. sitophila; $\mathrm{Pc}=$ P. chrysogenum; $\mathrm{Sc}=$ S. celluloflavus .

Figure 5 shows the MDS diagram for the samples studied. A nucleus can be seen very near to the blank sample, consisting of the samples inoculated with C. sitophila and treated with biocides. This indicates that there were no substantial chemical changes in the composition of the varnish. The type 3 samples (inoculated with a microorganism but with no biocide), however, appear very much grouped together and far from the control sample; this indicates the efficacy of the treatments tested in inhibiting microbial growth and also in preventing the appearance of chemical changes in the sandarac. 


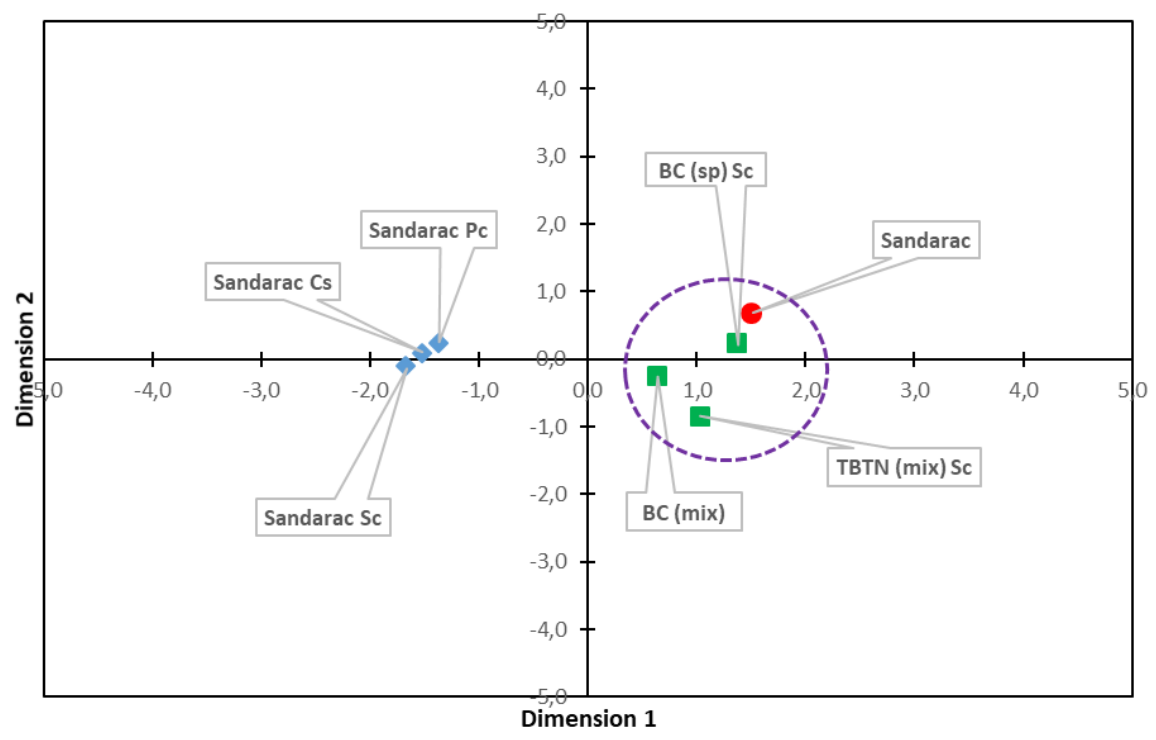

Figure 5. MDS analysis of the sandarac samples: blank sample (type 1, red circle); samples inoculated with microorganisms without biocide (type 3, blue diamonds); and samples inoculated with Pc, Cs and Sc, and treated with the studied biocides (type 4 (mix), and 5 (sp), green squares). BC = benzalkonium chloride, $\mathrm{TBTN}=$ tributyltin naphtenate, and $\mathrm{OPP}=$ ortophenyl phenol. $\mathrm{Cs}=\mathrm{C}$. sitophila; Pc $=$ P. chrysogenum; $\mathrm{Sc}=$ S. celluloflavus.

\subsection{Manila Copal}

Table 4 shows the analytical results for Manila copal. As with the other varnishes studied, the biocide treatments did not lead to any significant change in the composition of the original varnish, so the results for the type 2 samples are not included in the table. The study via microscope indicates that the treatments that were tested inhibited the growth of the fungi C. sitophila and P. herbarum in all such cases (Figure 6). As with the other two varnishes, the data corresponding to these latter samples are not included to simplify the study, since they are very similar to the data from blank samples.

As for the GC-MS analysis, in the samples inoculated with microorganisms but not treated with biocide, changes of little relevance occurred compared to the simple blank, most notably a decrease in the relative amount of agathalic acid, which oxidizes to agathic acid. Other trends seen were the moderate but generalized increase in the small peak for 19-norlabda-8 (20), 13-dien-15-oic acid and a decrease in acetoxy agatholic acid in $C$. sitophila, which agrees with the results obtained in previous studies [33].

The MDS statistical study (Figure 7) shows the results from all the samples somewhat grouped together to scale, indicating that in general the chemical changes occurring in the samples inoculated with microorganisms were not as clear as in the other varnishes studied. The results in the samples treated with biocides and inoculated with $A$. oxydans also appear in an area of the graph close to the uninoculated blank samples, indicating that the composition of the Manila copal was not substantially affected by the microorganisms tested and that the biocides therefore play a minor role in terms of the varnish's chemical composition. However, the treatments tested have shown to be efficient in controlling growth by inhibiting the development of mycelium in the samples inoculated with fungi. 

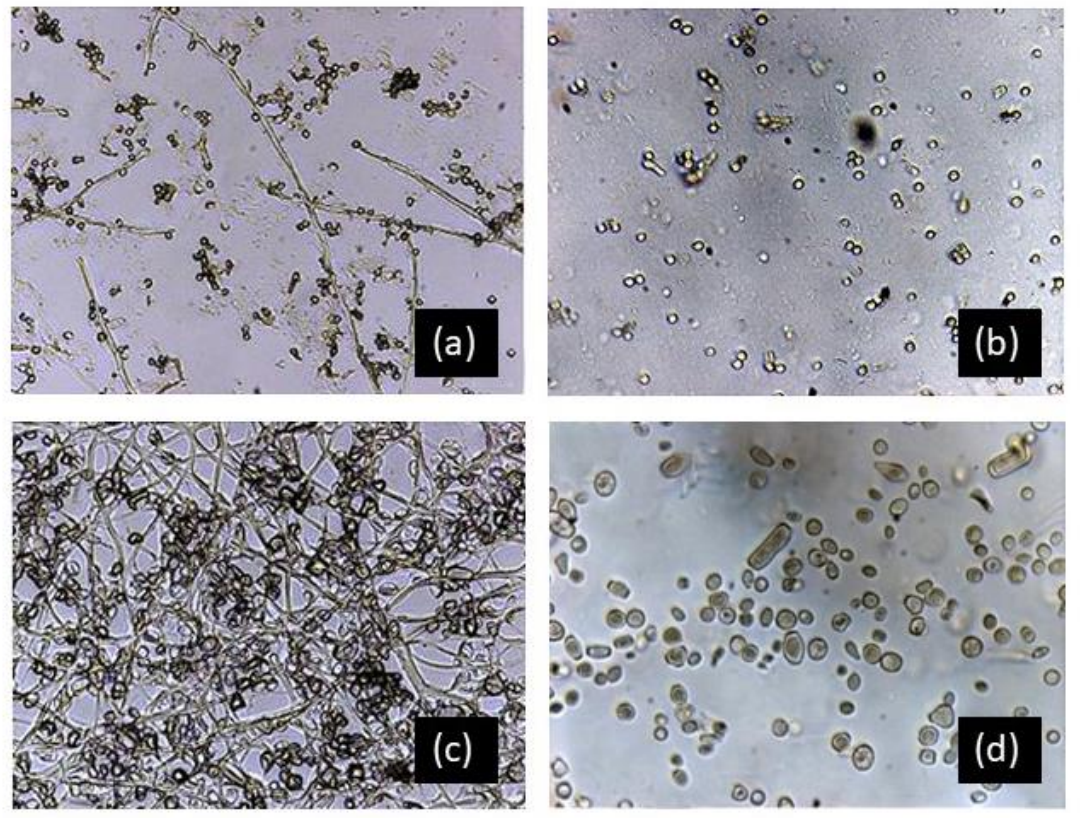

Figure 6. Microphotography (400×) showing fungal growth of (a) P. chrysogenum (sandarac) and (c) C. sitophila (Manila copal) after 5 days of incubation, images (b) and (d) show samples of sandarac treated with tributyltin naphthenate (mixed) and benzalkonium Chloride (mixed) in which no fungal growth was observed after the incubation period.

Table 4. GC-MS analysis ( $p<0.05$ in all cases) of the diterpenes free of Manila copal and the samples inoculated with microorganisms (values expressed in $\mathrm{Ni}$ ).

\begin{tabular}{|c|c|c|c|c|c|}
\hline Test & Sample Type & $\begin{array}{l}\text { 19-Norlabda-8 } \\
\text { (20), } \\
\text { 13-Dien-15-oic } \\
\text { Acid }\end{array}$ & $\begin{array}{c}\text { Agathalic } \\
\text { Acid }\end{array}$ & $\begin{array}{c}\text { Agathic } \\
\text { Acid }\end{array}$ & $\begin{array}{c}\text { Acetoxy } \\
\text { Agatholic Acid }\end{array}$ \\
\hline Manila copal & 1 & 3.24 & 7.35 & 41.66 & 23.28 \\
\hline Copal-Cs & 3 & 3.92 & 3.19 & 46.07 & 17.03 \\
\hline Copal-Ph & 3 & 3.92 & 1.93 & 39.07 & 19.81 \\
\hline Copal-Ao & 3 & 2.88 & 3.58 & 48.14 & 22.27 \\
\hline $\begin{array}{l}\text { Copal Benzalkonium } \\
\text { Chloride Ao }\end{array}$ & 4 & 3.31 & 1.05 & 46.18 & 28.06 \\
\hline $\begin{array}{l}\text { Copal Benzalkonium } \\
\text { Chloride (sp) Ao }\end{array}$ & 5 & 2.16 & 0.33 & 45.82 & 34.13 \\
\hline $\begin{array}{l}\text { Copal Tributyltin } \\
\text { naphthenate Ao }\end{array}$ & 4 & 1.30 & 0.49 & 40.59 & 33.85 \\
\hline $\begin{array}{l}\text { Copal Tributyltin } \\
\text { naphthenate (sp) Ao }\end{array}$ & 5 & 2.40 & 0.00 & 50.28 & 26.00 \\
\hline
\end{tabular}

Sample type: 1: varnish only (blank samples); type 3: varnish inoculated with microorganisms; types 4 and 5: varnish treated with benzalkonium chloride and tributyltin naphthenate mixed (4) or spread (5) and inoculated with microorganisms. $\mathrm{Cs}=\mathrm{C}$. sitophila; $\mathrm{Ph}=P$. herbarum; $\mathrm{Ao}=A$. oxydans. 


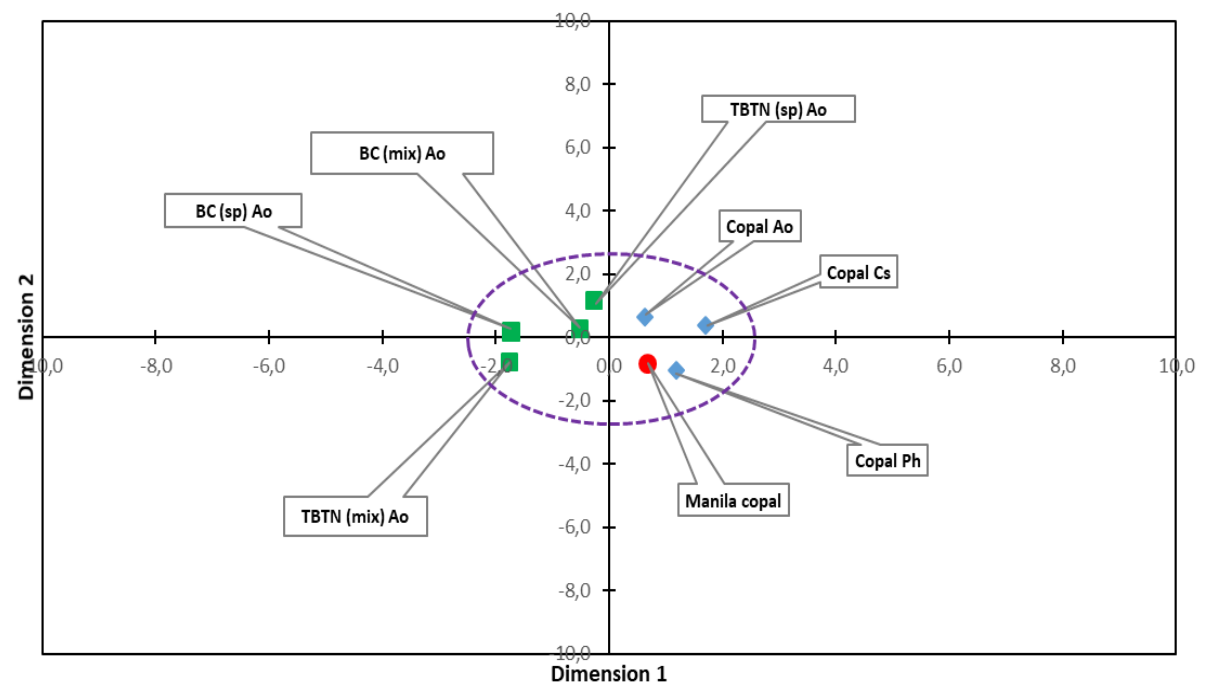

Figure 7. MDS analysis of Manila copal samples: blank sample (type 1, red circle); samples inoculated with microorganisms without biocide (type 3, blue diamonds); and samples inoculated with Ao and treated with the studied biocides (type 4 (mix), and 5 (sp), green squares). BC = benzalkonium chloride, $\mathrm{TBTN}=$ tributyltin naphtenate, and $\mathrm{OPP}=$ ortophenyl phenol. $\mathrm{Cs}=\mathrm{C}$. sitophila; $\mathrm{Ph}=$ P. herbarum; $\mathrm{Ao}=A$. oxydans.

\subsection{General Technical Considerations}

As regards the biocides' physical and chemical properties and the possible practical applications of the treatments, the best properties were observed in the varnishes treated with benzalkonium chloride. This biocide enabled stable mixes formulas to be formed with the three varnishes without altering their transparency, which is in keeping with its properties as an emulsifier [21,42]. Another advantage of benzalkonium chloride's nature as a surfactant is that it tends to be heavily absorbed and also tends to spread easily over the surface where it is applied, forming an antiseptic layer that lends protection for a long time [19,42]. In the case of orthophenylphenol, transparent formulas dispersions were not achieved with the two varnishes of greatest polarity (sandarac and Manila copal), which also occurred with Metatin N spread on sandarac. This varnish, which is soluble in alcohol, gave the most problems in the mixes' formulas with biocides tested. As for the aesthetic appearance and transparency of the treated varnishes, in general good results were achieved visually, except in the aforementioned cases, although this factor has not been studied in the long term using quantitative colorimetric tests.

The innocuousness of treatments for painting materials (especially for binders and pigments) is an important matter that remains to be studied in future. Perhaps the most tried and tested product on polychrome artworks among those tested is benzalkonium chloride, which is widely used for fresco paintings, whether in an aqueous solution or in mixtures for cleaning poultices such as "AB 57", commonly used in restoration [21,42]. It can therefore be considered with some confidence for pigments. It is also compatible with metals, which is not the case with Preventol ON. The latter is corrosive to them, thereby restricting its use in artworks with gold or silver [43].

Finally, human and environmental toxicity is another significant issue to take into account. Metatin N is the most toxic biocide tested here, since it contains tin (acute oral LD50 of $1300 \mathrm{mg} / \mathrm{kg}$ ) [4], which restricts its use in practical applications. Orthophenyl phenol is the least toxic of the three, since the formulations used do not irritate the skin or mucous membranes [44], whereas benzalkonium chloride is found to be somewhere in the middle, not showing special toxicity problems at the proposed concentrations [21].

\section{Conclusions}

New treatments were proposed to protect works of art against biodeterioration by using varnishes with biocidal activity, and three products were tested: benzalkonium chloride, orthophenyl phenol 
(Preventol ON), and tributyltin naphthenate (Metatin N) incorporated into the colophony, sandarac, and Manila copal varnishes, and also applied by spreading it onto them. In general, growth of the microorganisms tested was inhibited without causing significant chemical changes to the varnishes.

In the case of colophony resin, the biocidal treatments that were incorporated into the varnish inhibited the growth of the fungus $C$. sitophila. In the samples with the biocides spread onto the resin, a little fungal growth was observed, indicating less efficiency for treatments applied in this way. The GC-MS analytical results did not show significant changes in resins that were inoculated with C. sitophila and with B. amyloliquefaciens when compared to the uninoculated blank samples, since the increase observed in oxidized forms of the abietane diterpenes without biocides was not seen. However, an exception was seen in the treatment with tributyltin naphthenate mixed with the varnish, which was seen to be less effective against the bacteria.

In the sandarac varnish, the biocides that were tested (benzalkonium chloride and Metatin $\mathrm{N}$ incorporated into the varnish, and benzalkonium chloride spread on the varnish) inhibited the growth of the fungi $C$. sitophila and P. herbarum. The chemical changes observed in the varnish due to the microorganisms studied, including the bacterium S. celluloflavus, did not occur in the presence of biocides.

Lastly, in the Manila copal varnish, the biocides that were tested (benzalkonium chloride and Metatin $\mathrm{N}$ incorporated into the varnish and spread on it) inhibited the growth of the fungi $C$. sitophila and P. herbarum, although the GC-MS analysis did not show conclusive data as regards the efficacy of the treatments chemically.

The results from the study suggest that the addition of biocides to natural varnishes has significant potential as a factor in controlling the biodeterioration of cultural assets, though questions remain such as the permanence of these products on the artwork, the durability of the treatments and their efficacy, and innocuousness for the original materials in the long-term, which can be addressed in future publications.

Author Contributions: Conceptualization and work design, J.R.-N. and F.B.-G.; methodology, analyses, and investigation, J.R.-N. and R.B.-M.; writing, review, and editing, J.R.-N.; supervision, project administration, funding acquisition, F.B.-G. All authors have read and agreed to the published version of the manuscript.

Funding: This research was funded by the following projects: Desarrollo de Nuevas Sinergias Arte-Ciencia aplicadas a la Conservación y Restauración de los Palacios y Jardines de la Alhambra y el Generalife (VIRARTE), MINECO, with reference HAR2016-79886-P; Métodos sinérgicos Arte-Ciencia-Tecnología para la Conservación-Restauración de la Alhambra y otros Bienes Culturales (VIRARTE II), MICINN, with reference PID2019-109713RB-I00; La aplicación de las algas procedentes de la Alhambra y el Generalife en técnicas artísticas y de conservación-restauración (FICOARTE), Universidad de Granada, with reference A-HUM-279-UGR18; Aplicación avanzada de las algas procedentes de la Alhambra y el Generalife en técnicas artísticas y de conservación-restauración. Modalidad Frontera consolidado en el ámbito del Plan Andaluz de Investigación, Desarrollo e Innovación (PAIDI 2020), with reference P18-FR-4477.

Conflicts of Interest: The authors declare no conflict of interest. The funders played no part in designing the study or in collecting, analyzing or interpreting the data, in writing the manuscript, or in the decision to publish the results.

\section{References}

1. Ciferri, O.; Tiano, P.; Mastromei, G. Of Microbes and Art: The Role of Microbial Communities in the Degradation and Protection of Cultural Heritage; Springer Science \& Business Media: New York, NY, USA, 2000.

2. Allsopp, D.; Seal, K.; Gaylarde, C. Introduction to Biodeterioration; Cambridge University Press: Cambridge, UK, 2004.

3. Koestler, R.J.; Koestler, V.H.; Charola, A.E.; Nieto-Fernandez, F.E. Art, Biology, and Conservation: Biodeterioration of Works of Art; Yale University Press: New Haven, CT, USA, 2004.

4. Caneva, G.; Nugari, M.P.; Salvadori, O. Plant Biology for Cultural Heritage. Biodeterioration and Conservation; Getty Conservation Institute: Los Ángeles, CA, USA, 2009.

5. Tiano, P. Biodeterioration of monumental rocks: Decay mechanisms and control methods. Sci. Technol. Cult. Herit. 1998, 7, 19-38. 
6. Warscheid, T.; Braams, J. Biodeterioration of stone: A review. Int. Biodeterior. Biodegrad. 2000, 46, $343-368$. [CrossRef]

7. Scheerer, S.; Ortega-Morales, O.; Gaylarde, C. Microbial deterioration of stone monuments-An updated overview. Adv. Appl. Microbiol. 2009, 66, 97-139. [PubMed]

8. Salvadori, O.; Municchia, A.C. The Role of Fungi and Lichens in the Biodeterioration of Stone Monuments. Open Conf. Proc. J. 2016, 7 (Suppl. 1), 39-54. [CrossRef]

9. Tiano, P. Biodeterioration of Stone Monuments a Worldwide Issue. Open Conf. Proc. J. 2016, 7 (Suppl. 1), 29-38. [CrossRef]

10. Nugari, M.P.; D’Urbano, M.S.; Salvadori, O. Test methods for comparative evaluation of biocide treatments. In Proceedings of the International UNESCO/RILEM Congress on Conservation of Stone and Others Materials, Paris, France, 29 June-1 July 1993; Thiel, M.J., Ed.; E\&FN Spon: London, UK, 1993; pp. 565-572.

11. Koestler, R.J.; Salvadori, O. Methods of evaluating biocides for the conservation of porous building materials. Sci. Technol. Cult. Herit. 1998, 5, 1963-1968.

12. Malagodi, M.; Nugari, M.P.; Altieri, A.; Lonati, G. Effects of combined aplication of biocides and protectives on marble. In Proceeedings of the 9th International Congress on Deterioration and Conservation of Stone, Venice, Italy, 19-24 June 2000; Fassina, V., Ed.; Elsevier: Amsterdam, The Netherlands, 2000; Volume 2, pp. 225-233.

13. Nugari, M.P.; Salvadori, O. Biocides and treatment of stone: Limitation and future prospects. In Art, Biology and Conservation: Biodeterioration of Works of Art; Koestler, R.J., Koestler, V.H., Charola, E.A.E., Nieto-Fernandez, F.E., Eds.; The Metropolitan Museum of Art: New York, NY, USA, 2003; pp. 518-535.

14. Sterflinger, K.; Piñar, G. Microbial Deterioration of Cultural Heritage and Works of Art. Tilting at Windmills? Appl. Microbiol. Biotechnol. 2013, 97, 9637-9646. [CrossRef]

15. Mitova, M.; Iliev, M.; Novakova, A.; Gorbushina, A.; Groudeva, V.; Martín-Sánchez, P. Diversity and biocide susceptibility of fungal assemblages dwelling in the Art Gallery of Magura Cave, Bulgaria. Int. J. Speleol. 2017, 46, 67-80. [CrossRef]

16. Koestler, R.J.; Parreira, E.; Santoro, E.D.; Noble, P. Visual effects of selected biocides on easel painting materials. Stud. Conserv. 1993, 38, 265-273.

17. Poyatos, F.; Morales, F.; Nicholson, A.W.; Giordano, A. Physiology of biodeterioration on canvas paintings. J. Cell. Physiol. 2018, 233, 2741-2751. [CrossRef]

18. Bravery, A.F. Biodeterioration of paint-A state-of-the-art comment. In Biodeterioration 7; Houghton, D.R., Smith, R.N., Eggins, H.O.W., Eds.; Elsevier Applied Science: London, UK, 1988; pp. 466-485.

19. Caneva, G.; Nugari, M.P.; Pinna, D.; Salvadori, O. Il Controllo del Degrado Biologico; Nardini Editore: Florence, Italy, 1998; pp. 1-180.

20. Schieweck, A. Occurance of organic and inorganic biocides in the museum environment. Atmos. Environ. 2006, 41, 3266-3275. [CrossRef]

21. Nugari, M.P.; Salvadori, O. Biodeterioration control of cultural heritage: Methods and products. In Molecular Biology and Cultural Heritage; Sáiz-Jiménez, C., Ed.; Rouledge: London, UK, 2017; pp. 233-242. [CrossRef]

22. Ferone, C.; Pansini, M.; Mascolo, M.C.; Vitale, A. Preliminari study on the set up of mortars displaying biocidal activity. In Proceeedings of the 9th International Congress on Deterioration and Conservation of Stone, Venice, Italy, 19-24 June 2000; Fassina, V., Ed.; Elsevier: Amsterdam, The Netherlands, 2000; Volume 2, pp. 371-378.

23. Urzi, C.; de Leo, F. Evaluation of the efficiency of water-repellent and biocide compounds against microbial colonization of mortars. Int. Biodeterior. Biodegrad. 2007, 60, 25-34. [CrossRef]

24. Barrionuevo, M.R.E.; Gaylarde, C.C. Biocide-containing varnish for the protection of sandstone: Comparison of formulations and laboratory test methods. Curr. Microbiol. 2011, 62, 1671-1676. [CrossRef] [PubMed]

25. Capodicasa, S.; Fedia, S.; Porcellia, A.M.; Zannon, D. The microbial community dwelling on a biodeteriorated 16th century painting. Int. Biodeterior. Biodegrad. 2010, 64, 727-733. [CrossRef]

26. López-Miras, M.M.; Martín, I.; Yebra, A.; Romero-Noguera, J.; Bolívar, F.; Ettenauer, J.; Sterflinger, K.; Píñar, G. Contribution of the microbial communities detected on an oil painting on canvas to its biodeterioration. PLoS ONE 2013, 8, e80198. [CrossRef]

27. López-Miras, M.M.; Piñar, G.; Romero-Noguera, J.; Bolívar, F.C.; Ettenauer, J.; Sterflinger, K.; Martín, I. Microbial communities adhering to the obverse and reverse sides of an oil painting on canvas: Identification and evaluation of their biodegradative potential. Aerobiología 2013, 29, 301-314. 
28. de Carvalho, H.P.; Sequeira, S.O.; Pinho, D.; Trovao, J.; da Costa, R.M.F.; Egas, C.; Macedo, M.F.; Portugal, A. Combining an innovative non-invasive sampling method and high-throughput sequencing to characterize fungal communities on a canvas painting. Int. Biodeterior. Biodegrad. 2019, 145, 104816. [CrossRef]

29. Pínar, G.; Poyntner, C.; Lopandic, K.; Tafer, H.; Sterflinger, K. Rapid diagnosis of biological colonization in cultural artefacts using the MinION nanopore sequencing technology. Int. Biodeterior. Biodegrad. 2019, 148. [CrossRef]

30. Romero-Noguera, J.; Bolívar-Galiano, F.C.; Ramos-López, J.M.; Fernández-Vivas, M.A.; Martín-Sánchez, I. Study of biodeterioration of diterpenic varnishes used in art painting: Colophony and Venetian turpentine. Int. Biodeterior. Biodegrad. 2019, 62, 427-433. [CrossRef]

31. Romero-Noguera, J.; Martín-Sánchez, I.; López-Miras, M.M.; Ramos-López, J.M.; Bolívar-Galiano, F.C. Biodeterioration patterns found in dammar resin used as art material. Electron. J. Biotechnol. 2009, 13. [CrossRef]

32. Romero-Noguera, J.; López-Miras, M.M.; Martín-Sánchez, I.; Ramos-López, J.M.; Bolívar-Galiano, F.C. An approach to the study of the fungal deterioration of a classical art material: Mastic varnish. Electron. J. Biotechnol. 2010, 13. [CrossRef]

33. Romero-Noguera, J.; Doménech-Carbó, M.T.; Osete-Cortina, L.; Martín-Sánchez, I.; Bolívar-Galiano, F.C. Analytical characterisation of the biodeterioration of diterpenoid labdanic varnishes used in pictorial techniques: Sandarac and Manila copal. Int. Biodeterior. Biodegrad. 2014, 90, 99-105. [CrossRef]

34. De Souza, A.; Gaylarde, C.C. Biodeterioration of varnished wood with and without biocide: Implications for standard test methods. Int. Biodeterior. Biodegrad. 2002, 49, 21-25. [CrossRef]

35. Doménech-Carbó, M.T.; Osete-Cortina, L.; de la Cruz Cañizares, J.; Bolívar-Galiano, F.; Romero-Noguera, J.; Fernández-Vivas, M.A.; Martín-Sánchez, I. Study of the microbiodegradation of terpenoid resin-based varnishes from easel painting using pyrolysis-gas chromatography-mass spectrometry and gas chromatography-Mass spectrometry. Anal. Bioanal. Chem. 2006, 385, 1265-1280. [CrossRef]

36. Michaelsen, A.; Piñar, G.; Montanari, M.; Pinzari, F. Biodeterioration and restoration of a 16th-century book using a combination of conventional and molecular techniques: A case study. Int. Biodeterior. Biodegrad. 2009, 63, 161-168. [CrossRef]

37. Pastorova, I.; Van den Berg, K.J.; Boon, J.J.; Verhoeven, J.W. Analysis of oxidised diterpenoid acids using thermally assisted methylation with TMHA. J. Anal. Appl. Pyrolysis 1997, 43, 41-57. [CrossRef]

38. Van den Berg, K.J.; Boon, J.J.; Pastorova, I.; Spetter, L.F.M. Mass spectrometric methodology for the analysis of highly oxidized diterpenoid acids in Old Master paintings. J. Mass Spectrom. 2000, 35, 512-533. [CrossRef]

39. Scalarone, D.; Lazzari, M.; Chiantore, O. Ageing behaviour and pyrolytic characterisation of diterpenic resins used as art materials: Colophony and Venice turpentine. J. Anal. Appl. Pyrolysis 2002, 64, 345-361. [CrossRef]

40. Azemard, C.; Menager, M.; Vieillescazes, C. Analysis of diterpenic compounds by GC-MS/MS: Contribution to the identification of main conifer resins. Anal. Bioanal. Chem. 2016, 408, 6599-6612. [CrossRef]

41. Kononenko, I.; Viguerie, L.; Rochut, S.; Walter, P. Qualitative and quantitative studies of chemical composition of sandarac resin by GC-MS. Environ. Sci. Pollut. Res. 2017, 24, 2160-2165. [CrossRef]

42. GE International Institute for Conservation of Historic and Artistics Works. Available online: https: //www.geiic.com/files/fichas\%20productos/cloruro_de_benzalconio.pdf (accessed on 16 September 2020).

43. GE International Institute for Conservation of Historic and Artistics Works. Available online: https: //www.geiic.com/files/fichas\%20productos/preventol_ON.pdf (accessed on 16 September 2020).

44. Food and Agriculture Organization of the United Nations (FAO). Available online: http://www.fao. org/fileadmin/templates/agphome/documents/Pests_Pesticides/JMPR/Evaluation99/23Phenylphenol.pdf (accessed on 22 September 2020).

Publisher's Note: MDPI stays neutral with regard to jurisdictional claims in published maps and institutional affiliations. 